\title{
SPATIAL PRACTICES OF MOSQUES IN TOKYO
}

\author{
東京におけるモスクの空間的実践 \\ Amena RAHMAN ${ }^{* 1}$, Davina IWANA ${ }^{* 2}$, KeiSASAKI ${ }^{* 3}$ \\ and Yoshiharu TSUKAMOTO*4 \\ アメナラマン, ダヴィナイワナ，佐々木＼cjkstart啓，塚 本 由晴
}

\begin{abstract}
Muslims living in Tokyo have built mosques to continue their religious practices that have essential and unchanging religious behavioral norms, related to the architectural norms of the Minaret, Wudu, Salat, Mihrab, Minbar. Conflicts arise when the architectural norms encounter the existing physical setting of the city and they must be adapted to ensure that the behavioral norms can be practiced. This paper lists the mosques in Tokyo and, through interviews and field surveys, extracts patterns of adaptations of the architectural norms. This makes apparent the diverse practices of the mosque for the establishment of Muslim identities.
\end{abstract}

Keywords: Mosque, Muslim, Spatial practice, Adaptation, Behavior モスク，ムスリム，空間的実践，適応，ふるまい

\section{Introduction}

In a Muslim-majority country, the mosque is one of the significant urban facilities spread through the neighbourhoods. Mosques refer to the architectural heritage of each country, as well as the common elements found in Islamic architecture. As Japan is not Muslim־majority country, the number of mosques is quite small, though there has been an increase over the past years. In Tokyo, some mosques are newly built as religious facilities while others are renovated buildings. These religious facilities take on the additional roles of being places for education, business and social exchange and have variations resulting from the limitations they face in the physical urban condition of Tokyo. However, these limitations have produced creative ways to practice religious rituals by negotiating with the existing physical setting.

This study creates a framework where the typical mosque of a Muslim majority country is deconstructed into behavioral norms and their associated architectural norms. Through this deconstruction, the key sequence that must be maintained by the facility in order to be used as a mosque in Tokyo is highlighted. The spatial practices of this sequence involve the necessary modifications of interior spaces as well as the symbolic adaptations to the exterior. This study aims to analyze mosques in Tokyo to illustrate how architectural norms may be modified through the encounter between Tokyo conditions and religious behavioral norms.

Muslims are a part of the people coming to Japan from different countries who bring with them their own methods of worship ${ }^{1)}$. Tanada Hirofumi provides a broad overview of the Muslim population residing in Japan and their communal efforts to construct mosques through the utilization of their migrant network and the self-mobilization of their financial resources. In addition, Tanada also looks at the role the mosque plays in the lives of this communi$\mathrm{ty}^{2}$. Also on the broader scale, Tanada Hirofumi and Okai Hirofumi chart a historical record of mosques built at a country-wide scale in Japan and analyze the network between them. They critically analyse the relation of the growing community of Muslims with the local Japanese population ${ }^{3}$. Okai looks at the religious solidarity and mobilization of financial capital from within the migrant networks that lead to the establishment of mosques ${ }^{4}$. Narrowing the
"1 Ph.D. Candidate, Dept. of Architecture and Building Engineering, School of Environment and Technology, Tokyo Institute of Technology, M.Eng. Freelance, M.Eng.

*3 Assist. Prof., Dept. of Architecture and Building Engineering, School of Environment and Technology, Tokyo Institute of Technology, Dr.Eng.

4 Prof., Dept. of Architecture and Building Engineering, School of Environment and Technology, Tokyo Institute of Technology, Dr.Eng.

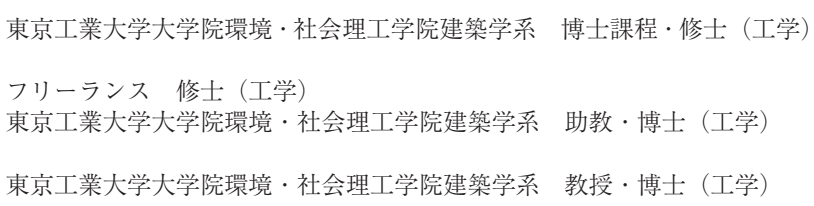


focus to Tokyo, there is information on the development of non-permanent religious spaces of Muslims, called musallahs, into permanent mosques, and the social functions they perform ${ }^{5}$ ) and the daily obstacles that must be overcome ${ }^{6}$.

However, there is not much research from the viewpoint of the adaptations of architectural norms and their spatial relationships from typical mosques of Muslim countries into mosques in Tokyo. This research looks to the Lefebvrian concepts of spatial practices ${ }^{7)}$ to analyze how sacralization through ritual behavior materially and ideologically produces distinctive religious spaces ${ }^{8}$. According to Lefebvre, spatial practices are those actions that take place within the lived space and give it structure. The collective practice gives the space meaning. As will be discussed in this study, the mosques in Tokyo vary highly in building typology, people and organization. However, by looking through the lens of spatial practices, we can analyze all the cases in this study within a single framework.

\section{Methodology}

In the methodology, the typical mosque in a Muslim country is deconstructed to understand the sequence of behavioral norms and their associated architectural norms (Fig.1).

\subsection{The Behavioral and Architectural Norms of a Mosque}

The purpose of the mosque is to provide a congregation space to perform the ritual of prayer called Salat in a communal way. A sequence of "behavioral norms" is followed: Adhan - the call to prayers, a vocal announcement that alerts the neighbourhood that the time for a specific prayer has begun; Wudu - an ablution performed prior to prayer; Iqamah - the second call to prayer within the mosque that signals the immediate beginning of Salat. Salat - the actual ritual of prayer that must be performed facing Makkah. The leader of the prayer is called the Imam. The rows of the congregation stand behind the Imam, collectively called the Jamaah, while facing Makkah. In addition, a sermon called the Khutbah is given each Friday, the day of congregation in Islam.

The behavioral norms are associated with "architectural norms"

(Fig.1). The behavioral norm of Adhan is given at the architectural norm of the Minaret, a typical element of Islamic architecture. The behavioral norm of Wudu is performed in the architectural norm of the Wudu area. The behavioral norm of Salat is given in the main prayer area, termed as the Salat area, but can also performed in any space of the mosque. During Salat, the Imam and Jamaah face the Mihrab, which is a niche in the wall in the direction of the Makkah. The Iqamah and Khutbah have the interior architectural element of the Minbar, a small, low platform that raises the Imam so that they congregation may see and hear him clearly. ${ }^{9)}$

It is these fundamental architectural norms that need to be adapted in order to create a mosque in Tokyo. Furthermore, it is necessary to study the Minaret, Salat and Wudu areas in relation with each other, as only when taken together do they have a religious implication. For example, the Minaret in isolation is just a tower. Only

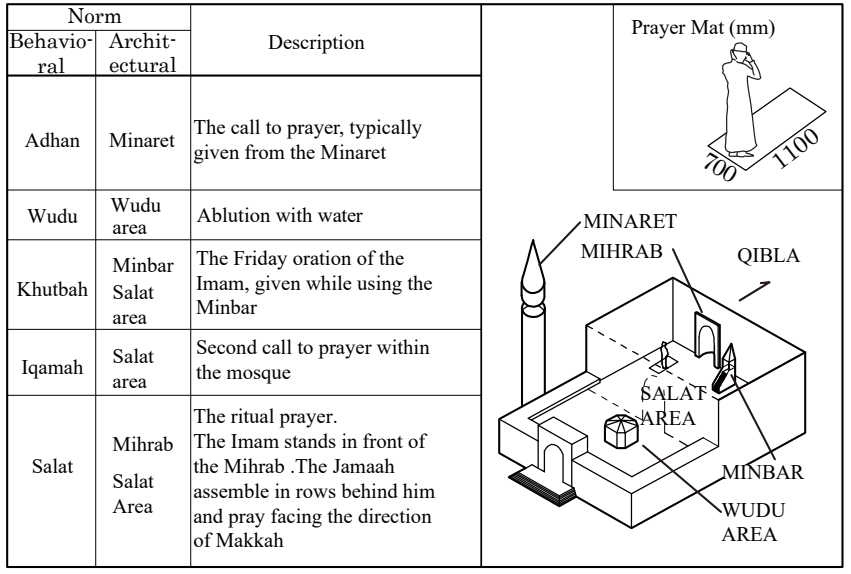

Fig. 1 Behavioral and Architectural Norms of Mosques in Tokyo

Table 1 Location of Case Studies in Tokyo

\begin{tabular}{|c|c|c|c|c|c|c|}
\hline \multirow{2}{*}{ Map } & No & \multicolumn{2}{|l|}{ Mosque } & \multirow{3}{*}{$\begin{array}{c}\text { Location } \\
\text { Asakusa }\end{array}$} & \multicolumn{2}{|r|}{ Building } \\
\hline & & & F.Yr & & Year & ndition \\
\hline & 1 & Dar al Arqam & 2000 & & 1995 & Renovated -Ov \\
\hline & 2 & Tokyo Camii & 1938 & Yoyogi Uehara & 2000 & New \\
\hline & 3 & Otsuka & 1999 & Otsuka & 2000 & Renovated -Ov \\
\hline & 4 & Al Tauheed & 2002 & Hachioji & 2002 & New \\
\hline & 5 & Hiroo (AI) & 1982 & Hiroo & 2000 & New -Pa \\
\hline & 6 & Makki & 1995 & Ohanachaya & 2001 & Renovated -Ov \\
\hline & 7 & Assalam & 2010 & Okachimachi & 2010 & Renovated -Ov \\
\hline & 8 & Kamata & 2013 & Kamata & 2014 & Renovated -Ov \\
\hline & 9 & Al Ikhlas & 2016 & Kabukicho & 2016 & Renovated -Ov \\
\hline & 10 & Indonesia & 1962 & Meguro & 2017 & New \\
\hline & 11 & Nusantara & 2019 & Akihabara & 2019 & Renovated -Pa \\
\hline
\end{tabular}

F.Yr - Founding Year

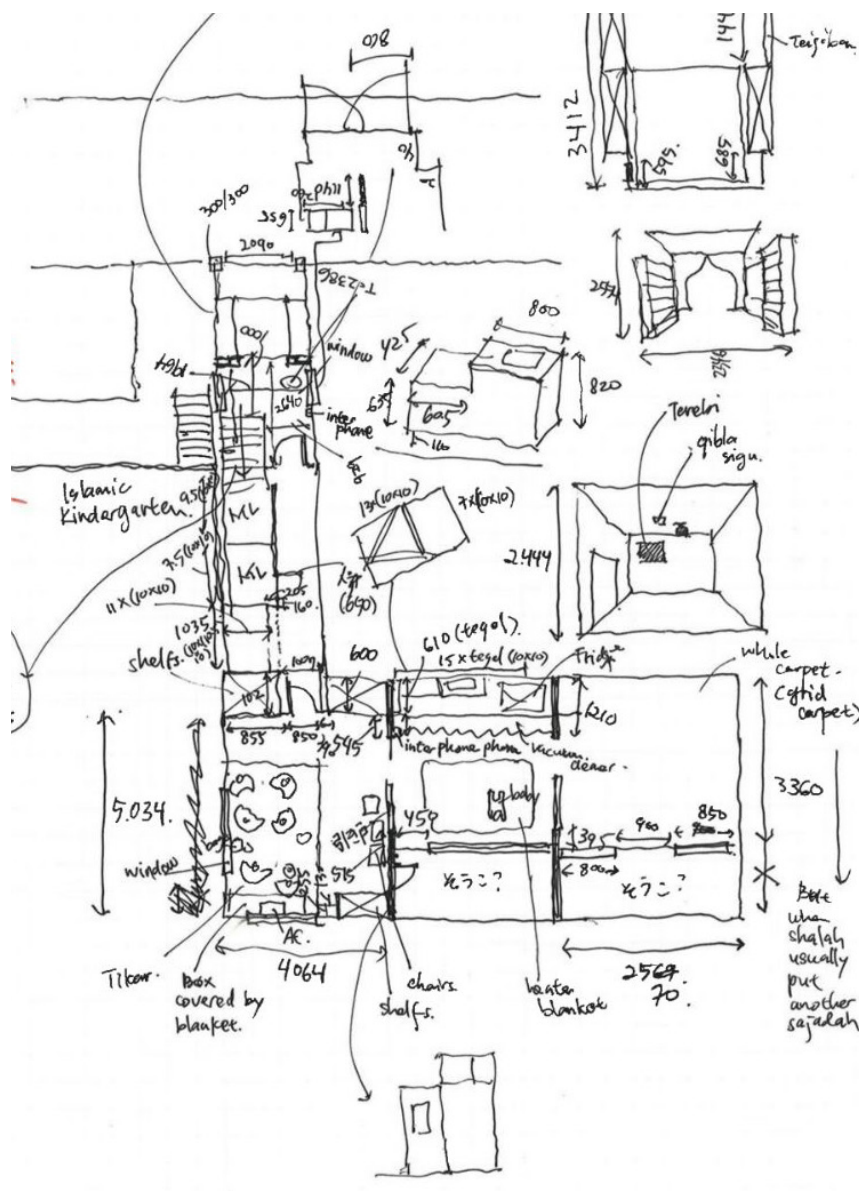

Fig. 2 Example of Field Survey of Otsuka Mosque 
Table 2 Interview Summary

\begin{tabular}{|c|c|c|c|c|c|c|c|c|c|c|c|c|c|}
\hline \multicolumn{3}{|c|}{ Mosque } & \multirow{2}{*}{$\begin{array}{l}\text { 1.Dar Al } \\
\text { Arqam } \\
\\
\text { Office } \\
\text { Building }\end{array}$} & \multirow{2}{*}{$\begin{array}{c}\text { 2.Tokyo Camii } \\
\text { New } \\
\text { Building }\end{array}$} & \multirow{2}{*}{$\begin{array}{l}\text { 3. Otsuka } \\
\text { Office for } \\
\text { printing } \\
\text { company }\end{array}$} & \multirow{2}{*}{\begin{tabular}{|c|} 
4. Al Tauheed \\
New \\
Building
\end{tabular}} & \multirow{2}{*}{\begin{tabular}{|c|} 
5.Hiroo- \\
Arab Institute \\
\\
New \\
Building \\
\end{tabular}} & \multirow{2}{*}{$\begin{array}{c}\text { 6. Makki } \\
\begin{array}{c}\text { Office for } \\
\text { electronics } \\
\text { manufacturer }\end{array}\end{array}$} & \multirow{2}{*}{$\begin{array}{l}\text { 7. Assalam } \\
\begin{array}{c}\text { Residential } \\
\text { apartment } \\
\text { building }\end{array}\end{array}$} & \multirow{2}{*}{\begin{tabular}{c|} 
8. Kamata \\
Residential \\
apartment \\
building with \\
laundromat
\end{tabular}} & \multirow{2}{*}{$\begin{array}{l}\text { 9. Al Ikhlas } \\
\text { Residential } \\
\text { apartment } \\
\text { building and } \\
\text { izakaya }\end{array}$} & \multirow{2}{*}{\begin{tabular}{|c|} 
10. Indonesia \\
New \\
Building
\end{tabular}} & \multirow{2}{*}{$\begin{array}{c}\text { 11. Nusantara } \\
\begin{array}{c}\text { Office for } \\
\text { construction } \\
\text { company }\end{array}\end{array}$} \\
\hline & Previous & Use & & & & & & & & & & & \\
\hline \multirow{3}{*}{ 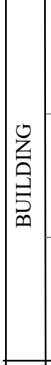 } & \multicolumn{2}{|c|}{$\begin{array}{l}\text { Building / Plot } \\
\text { Selection }\end{array}$} & $\begin{array}{c}\text { Selected by } \\
\text { Islamic Center } \\
\text { of Japan }\end{array}$ & $\begin{array}{c}\text { Plot owned } \\
\text { by Turkish } \\
\text { Government }\end{array}$ & $\begin{array}{l}\text { Selected by } \\
\text { community }\end{array}$ & $\begin{array}{c}\text { Plot donated } \\
\text { by Saudi } \\
\text { Arabian } \\
\text { businessowner }\end{array}$ & $\begin{array}{l}\text { The Institute } \\
\text { was donated by } \\
\text { the Saudi } \\
\text { Arabian govt. }\end{array}$ & $\begin{array}{l}\text { Selected by } \\
\text { community }\end{array}$ & $\begin{array}{c}\text { Selected by } \\
\text { Islamic Center } \\
\text { of Japan }\end{array}$ & $\begin{array}{c}\text { Asked local } \\
\text { people and } \\
\text { found through } \\
\text { a developer }\end{array}$ & $\begin{array}{l}\text { Owned by } \\
\text { Indonesian } \\
\text { community } \\
\text { member }\end{array}$ & $\begin{array}{c}\text { Built beside } \\
\text { the Indonesian } \\
\text { School }\end{array}$ & $\begin{array}{l}\text { Owned by } \\
\text { friend of the } \\
\text { chairperson } \\
\text { of Al Ikhlas }\end{array}$ \\
\hline & \multicolumn{2}{|c|}{ Interior Layout } & $\begin{array}{c}\text { Layout by } \\
\text { Islamic Center } \\
\text { of Japan }\end{array}$ & $\begin{array}{c}\text { Construction } \\
\text { company } \\
\text { employed by } \\
\text { mosque } \\
\text { organization }\end{array}$ & $\begin{array}{c}\text { Layout by } \\
\text { Islamic Center } \\
\text { of Japan }\end{array}$ & $\begin{array}{l}\text { Layout by } \\
\text { mosque } \\
\text { organization }\end{array}$ & $\begin{array}{l}\text { Designed as } \\
\text { part of the } \\
\text { Institute }\end{array}$ & $\begin{array}{l}\text { Decided by } \\
\text { community } \\
\text { suggestions }\end{array}$ & $\begin{array}{c}\text { Decided by } \\
\text { chairperson } \\
\text { with } \\
\begin{array}{c}\text { Islamic Center } \\
\text { of Japan }\end{array}\end{array}$ & $\begin{array}{l}\text { Decided by } \\
\text { community } \\
\text { suggestions }\end{array}$ & $\begin{array}{l}\text { Decided by } \\
\text { owner and } \\
\text { Indonesian } \\
\text { trainees }\end{array}$ & $\begin{array}{c}\text { Indonesian } \\
\text { architect who } \\
\text { studied with } \\
\text { local architect }\end{array}$ & $\begin{array}{l}\text { Decided by } \\
\text { community } \\
\text { suggestions }\end{array}$ \\
\hline & \multicolumn{2}{|c|}{ Building Method } & $\begin{array}{l}\text { DIY work by } \\
\text { community } \\
\text { members }\end{array}$ & $\begin{array}{c}\text { Japanese } \\
\text { contractors } \\
\text { with } \\
\text { Turkish } \\
\text { craftsmen } \\
\end{array}$ & $\begin{array}{l}\text { Japanese } \\
\text { contractor }\end{array}$ & $\begin{array}{l}\text { Japanese } \\
\text { contractor }\end{array}$ & $\begin{array}{l}\text { Japanese } \\
\text { contractor }\end{array}$ & $\begin{array}{l}\text { DIY work by } \\
\text { community } \\
\text { members }\end{array}$ & $\begin{array}{l}\text { Japanese } \\
\text { contractor }\end{array}$ & $\begin{array}{l}\text { Carpenter } \\
\text { hired by } \\
\text { community } \\
\text { donations }\end{array}$ & $\begin{array}{l}\text { Indonesian } \\
\text { carpentry } \\
\text { trainees }\end{array}$ & $\begin{array}{l}\text { Japanese } \\
\text { contractor }\end{array}$ & $\begin{array}{l}\text { Indonesian } \\
\text { carpentry } \\
\text { trainees }\end{array}$ \\
\hline \multirow{4}{*}{ 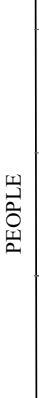 } & \multicolumn{2}{|c|}{ Mosque Funding } & $\mathrm{CE}$ & GB & $\mathrm{CE}$ & $\mathrm{CE}$ & GB & $\mathrm{CC}$ & $\mathrm{CE}$ & $\mathrm{CC}$ & $\mathrm{F}$ & $\mathrm{CE}$ & $\mathrm{CE}$ \\
\hline & \multicolumn{2}{|c|}{ Administration } & $\begin{array}{c}\text { Organization - } \\
\text { Islamic Center } \\
\text { of Japan }\end{array}$ & \begin{tabular}{|c|}
$\begin{array}{c}\text { Turkish govt. } \\
\text { organization } \\
\text { Directorate of } \\
\text { Religious } \\
\text { Affairs }\end{array}$ \\
\end{tabular} & $\begin{array}{c}7 \text { person } \\
\text { committee } \\
\text { registered as an } \\
\text { organization }\end{array}$ & $\begin{array}{c}2 \text { Imams and } 1 \\
\text { adminstrative } \\
\text { employee }\end{array}$ & $\begin{array}{c}\text { The Arab } \\
\text { Institute's } \\
\text { organization }\end{array}$ & $\begin{array}{l}\text { Organization } \\
\text { known as } \\
\text { Tabligh } \\
\text { Jamaat* }\end{array}$ & $\begin{array}{c}\text { Chairperson, } \\
\text { Imam and } \\
\text { administrative } \\
\text { assistant }\end{array}$ & $\begin{array}{c}\text { Committee } \\
\text { registered as a } \\
\text { corporation }\end{array}$ & $\begin{array}{c}\text { Committee of } \\
\text { Indonesian } \\
\text { members }\end{array}$ & $\begin{array}{l}\text { Organization } \\
\text { known as } \\
\text { KMII ** }\end{array}$ & $\begin{array}{c}\text { Committee of } \\
\text { Indonesian } \\
\text { members }\end{array}$ \\
\hline & \multicolumn{2}{|c|}{ Imam } & $\begin{array}{c}1 \text { Imam, } \\
\text { accommodated } \\
\text { in the mosque }\end{array}$ & $\begin{array}{c}2 \text { Imams. } \\
1 \text { for religious } \\
\text { activities, } 1 \text { for } \\
\text { management }\end{array}$ & $\begin{array}{l}\text { No fixed } \\
\text { Imam }\end{array}$ & $\begin{array}{c}2 \text { Imams. Live } \\
\text { with family, } \\
\text { accommodated } \\
\text { in mosque }\end{array}$ & $\begin{array}{c}3 \text { Imams from } \\
\text { the staff of the } \\
\text { organization. } \\
\text { Live nearby }\end{array}$ & $\begin{array}{l}2 \text { Imams } \\
\text { invited from } \\
\text { outside Japan }\end{array}$ & $\begin{array}{c}\text { Guest Imam } \\
\text { from different } \\
\text { countries }\end{array}$ & $\begin{array}{c}\text { Imam } \\
\text { employed by } \\
\text { the mosque. } \\
\text { Lives with } \\
\text { family nearby }\end{array}$ & $\begin{array}{c}1 \text { Imam is } \\
\text { from AlIkhlas, } \\
\begin{array}{c}1 \text { Imam from } \\
\text { Nusantara } \\
\text { mosque }\end{array}\end{array}$ & $\begin{array}{l}4 \text {-5 Imam. } \\
\text { Teachers and } \\
\text { student } \\
\text { volunteer }\end{array}$ & $\begin{array}{c}\text { Same Imam } \\
\text { from Al Ikhlas } \\
\text { mosque }\end{array}$ \\
\hline & \multicolumn{2}{|c|}{ Visitors } & $\begin{array}{l}\text { Families, } \\
\text { students, } \\
\text { workers, } \\
\text { tourists }\end{array}$ & $\begin{array}{l}\text { Families, } \\
\text { students } \\
\text { workers, } \\
\text { tourists }\end{array}$ & $\begin{array}{c}\text { Families, } \\
\text { mothers with } \\
\text { children, single } \\
\text { workers }\end{array}$ & \begin{tabular}{|c|} 
Families, \\
Students from \\
different \\
countries
\end{tabular} & $\begin{array}{c}\text { Staff, people } \\
\text { working in the } \\
\text { vicinity, } \\
\text { passerbys }\end{array}$ & $\begin{array}{l}\text { Male office } \\
\text { workers, } \\
\text { self-employed, } \\
\text { students. }\end{array}$ & $\begin{array}{l}\text { Multiethnic } \\
\text { regular } \\
\text { attendees, } \\
\text { tourists }\end{array}$ & $\begin{array}{l}\text { Single workers } \\
\text { from different } \\
\text { countries }\end{array}$ & $\begin{array}{l}\text { Indonesian } \\
\text { students, } \\
\text { trainees, } \\
\text { workers }\end{array}$ & $\begin{array}{l}\text { Residents, } \\
\text { school } \\
\text { employees, } \\
\text { trainees }\end{array}$ & $\begin{array}{l}\text { Indonesian } \\
\text { students, } \\
\text { trainees, } \\
\text { workers }\end{array}$ \\
\hline \multirow{7}{*}{ 柋 } & $\begin{array}{l}\text { Communa } \\
\text { Prepara }\end{array}$ & $\begin{array}{l}\text { Meal } \\
\text { tion }\end{array}$ & $\begin{array}{l}\text { Cooked by } \\
\text { volunteers, } \\
\text { order from } \\
\text { restaurants }\end{array}$ & $\begin{array}{c}\text { Turkish chef. } \\
\text { Free lunch on } \\
\begin{array}{c}\text { Friday by } \\
\text { volunteer } \\
\text { cooks }\end{array} \\
\end{array}$ & $\begin{array}{c}\text { Volunteers and } \\
\text { donations by } \\
\text { Muslim } \\
\text { restaurant }\end{array}$ & \begin{tabular}{|c|} 
Donated \\
Friday lunch \\
from Egyptian \\
restaurant \\
owner \\
\end{tabular} & $\begin{array}{c}\text { Institute staff } \\
\text { chef, order } \\
\text { bread from } \\
\text { local bakery }\end{array}$ & $\begin{array}{l}\text { Cooked by } \\
\text { volunteers } \\
\text { from } \\
\text { community }\end{array}$ & $\begin{array}{c}\text { Employed chef } \\
\text { using the } \\
\text { mosque } \\
\text { kitchen }\end{array}$ & $\begin{array}{l}\text { From } \\
\text { restaurant. } \\
\text { Volunteers } \\
\text { prepare in } \\
\text { Ramadan } \\
\end{array}$ & $\begin{array}{l}\text { Prepared by } \\
\text { Al Ikhlas } \\
\text { chairperson }\end{array}$ & $\begin{array}{l}\text { Volunteers or } \\
\text { have catering }\end{array}$ & $\begin{array}{l}\text { Al Ikhlas } \\
\text { chairperson } \\
\text { and } \\
\text { volunteers }\end{array}$ \\
\hline & \multicolumn{2}{|c|}{ Ramadan } & $\begin{array}{c}\text { Meals at sunset } \\
\text { and sunrise. } \\
\text { Night prayers }\end{array}$ & $\begin{array}{l}\text { Sunset meal } \\
\text { and night } \\
\text { prayers. } \\
\text { Lectures }\end{array}$ & $\begin{array}{c}\text { Sunset meal } \\
\text { and night } \\
\text { prayers. } \\
\text { Sermons by } \\
\text { guest lecturers }\end{array}$ & $\begin{array}{l}\text { Sunset meal } \\
\text { prepared by } \\
\text { Imam and } \\
\text { volunteers }\end{array}$ & $\begin{array}{c}\text { Night prayers } \\
\text { Lectures }\end{array}$ & $\begin{array}{l}\text { Sunset and } \\
\text { sunrise meals } \\
\text { in Ramadan. } \\
\text { Daily prayers }\end{array}$ & $\begin{array}{l}\text { Sunset meals. } \\
\text { Night prayers. } \\
\text { Lecturers from } \\
\text { other countries }\end{array}$ & $\begin{array}{c}\text { Meals at sunset } \\
\text { and sunrise. } \\
\text { Night prayers }\end{array}$ & $\begin{array}{l}\text { Invite Imam } \\
\text { and scholars } \\
\text { from Indonesia }\end{array}$ & $\begin{array}{c}\text { Meals at } \\
\text { sunset and } \\
\text { sunrise. Night } \\
\text { prayers. } \\
\text { Lectures } \\
\end{array}$ & $\begin{array}{c}\text { Meals at sunset } \\
\text { and sunrise. } \\
\text { Night prayers }\end{array}$ \\
\hline & \multirow{2}{*}{$\begin{array}{l}\text { Jamaah } \\
\text { Capacity }\end{array}$} & Friday & 130 & 100 & 200 & 150 & 500 & 200 & 500 & 200 & 40 & 200 & 100 \\
\hline & & Eid & 300 & 6000 & 700 & 300 & 1500 & 300 & 1000 & 600 & - & 500 & 400 \\
\hline & \multicolumn{2}{|c|}{\begin{tabular}{|l|} 
Multiple Prayers \\
\end{tabular}} & & 0 & 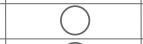 & 0 & $\checkmark$ & - & & & - & O & 0 \\
\hline & \multicolumn{2}{|c|}{ Communal Meal } & 0 & - & 0 & - & O & O & & 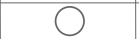 & - & & \\
\hline & \multicolumn{2}{|c|}{ ther rooms for Salat } & 0 & 0 & O & O & O & 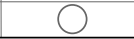 & $\checkmark$ & 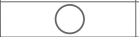 & O & 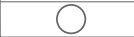 & $\checkmark$ \\
\hline
\end{tabular}

*) Tablighi Jamaat is an international Islamic Missionary Movement **) Keluarga Masyarakat Islam Indonesia (KMII) is an Indonesian Islamic missionary organization

when it is attached to the Salat area and the Wudu area does it become significant ${ }^{9)}$.

\section{Scope of study}

This research focuses on the existing eleven congregational mosques $^{* 1}$ in Tokyo (Table 1). and does not include smaller, temporary prayer spaces known as "musallahs"10). The term "musallah" refers to different typologies in different languages. Therefore, to avoid misrepresentation, the physical space in which the Salat is practiced will be referred to as the Salat area and the space for practicing Wudu will be called the Wudu area.

\subsection{Case studies of Tokyo Mosques}

Ten out of the eleven case studies are owned buildings except for Nusantara (No.11), which is a rented space. In Table 1, the Founding Year refers to when the mosque was founded. Building Year refers to the year the current building started to be used as a mosque, according to the interviews that were conducted. They are divided into two types: New Building and Renovated Building (Table 1).
Four mosques (No. 2, No.4, No.5, No.10) have been purpose-built as mosques with new buildings $[\mathrm{N}]$, with Hiroo mosque (No.5) categorized as New-Pa as it was designed as part of the cultural complex of the Arab Institute building. The remaining seven are Renovated Buildings, having adapted existing built structures. The buildings are further subdivided into Overall [Ov] as they have been completely renovated according to the requirements of the mosque (No.1, No.3, No.6, No.7, No.8, No.9, No.11); and Partial [Pa] Nusantara (No.11) is categorized as Renovated -Pa as it uses only the fifth floor of an office building. The other floors of this building are unrelated to the Nusantara mosque. The physical space of each of the mosques was measured and the articulation within the building was recorded (Fig. 2).

\subsection{Interviews of the Case Studies}

The interviews were held in the later half of 2018 with the administration, the Imams as well as visitors to each of the case studies. The interviews uncovered the integral role it plays in the visitors' lives. 


\section{Management of the Mosques}

The information compiled from the interviews is structured into sections of Building, People and Activities (Table 2). The section of Building shows the degrees of involvement of the local Muslim community and the different approaches taken in establishing a mosque. People are the driving force in each of the mosques and this section looks at who administrate and visit the mosque in order to keep it alive. The section of Activities shows how the mosque is sustained through the activities of the people who visit it.

\subsection{Building}

The selection of the plot or building are quite varied and depends on the resources available to the users of the mosque. For example, $\mathrm{Al}$ Tauheed (No.4) had its plot donated by a businessman while Kamata mosque's (No.8) building was purchased through community donations. In contrast, Tokyo Camii (No.2) and Hiroo (No.5) are owned by government organizations. The interior layout of the Wudu area and the Salat area, direction of Makkah etc. are considered by the people who are using the mosques. Four of the eleven mosques' plots (No.6, No.8, No.9, No.11) and their interior layouts have been decided by community suggestions, reflecting participation in being a part of the origin of the mosque as well as taking part in its activities. Three mosques are purpose-built by international organizations: Tokyo Camii (No.2), the Indonesia mosque (No.10) and Hiroo (No.5). Three mosques (No.1, No.3, No.7) consulted with a national organization, the Islamic Centre of Japan, for building or interior layout. Al Tauheed (No.4) used its own organization.

Participation is also reflected in the building method of the mosque as well. Four of the mosques (No.1, No.6, No.9, No.11) had members of the mosque community participate in physically renovating the building by themselves while the remaining mosques hired Japanese contractors.

\subsection{People}

The construction of the mosque requires financial assistance. The mosques can be placed in three categories according to the method in which they were funded ${ }^{*}$ : Government Based (GB), Community Charity (CC) and Community with External Assets (CE). In Government Based, the government of a specific country undertakes the responsibility of the mosque (No.2, No.5). The purchase of the land, construction of the building and the mosque's internal administration is all done by the government organization. In Community Charity mosques, a group of people pool their resources to purchase or rent the space for the mosque and undertake all associated modifications to the building as well as the administration (No.6, No.8). In Community with External Assets, a group of people are supported by a government or non-governmental organization to establish a mosque (No.1, No.3, No.4, No.7, No.9, No.10, No.11). In the administration of the mosques, five are done so by organizations (No.1, No.2, No.5, No.6, No.10). The remaining mosques have the responsibility of the religious and administrative management taken by an offcial committee (No.3, No.8, No.9, No.10, No.11) or a volunteer group
(No.4, No.7). The Imam is often part of this group. He is responsible for leading the prayers and managing religious activities that take place within the mosque. The Imam is usually selected according to the needs of the visitors to the mosque, as language and culture can be barriers in a foreign country. For example, in Tokyo Camii (No.2), the Friday Khutbah is given in English and Japanese. Much of the information literature, such as educational pamphlets, use English, Japanese and Turkish. The Indonesia mosque (No.10) which has been built next to the Indonesian school primarily uses the Indonesian language. Dar-Al-Arqam (No.1), established by a group of Pakistani people, uses both a combination of Urdu and English.

\subsection{Activities}

Mosques in Tokyo encourage their use by holding activities, such as communal meals during the month of Ramadan and the biannual celebrations of Eid. Food often poses an issue for the Muslim community living in Tokyo, which is why many activities are centered around communal meals. Two out of the eleven of the mosques have employed chefs (No.5, No.7) while the remaining have free meals prepared or donated by volunteers. Ramadan is when Muslims fast for the entire month. The sunrise and sunset meals are provided by the mosque, in addition to different lectures and prayers being held. Friday is considered as the day for communal prayers and sees an increase in the number of visitors, often maximizing the capacity of the mosque. While numbers for daily visitors could not be determined, the number of visitors on Fridays and during Eid were available as the administrations need to calculate the capacity of the mosque. In order to accommodate these cyclical fluctuations, each of the mosques have developed their own space management systems. For example, on Friday in a Muslim majority country, the noon prayer of Zuhr is given only once as there are mosques in every neighbourhood. On the other hand, on Friday in Tokyo, the Zuhr prayer is given multiple times in some of the mosques. This is due to the fact that the small number of mosques scattered across the city. Their size is also quite small and cannot fit the number of worshippers who make a special trip for Friday prayers. Therefore, to ensure everyone has their turn, the prayers are given in shifts, using the other rooms that are usually reserved for classes and other activities for Salat.

By looking into the management of the mosques, it is seen that there is a degree of involvement of the worshippers in the different phases of establishment, such as physically building the mosque, financial assistance or volunteering in the administration. In spite of the language barriers, the visitors who worship at the mosque and participate in the activities are highly diverse. Participation is also stimulated by the activities as by holding communal meals, celebrating religious days and social gatherings, the mosques strengthen ties between its members.

\section{Adaptations of Mosques in Tokyo}

In order to understand how the architectural norms are translated 


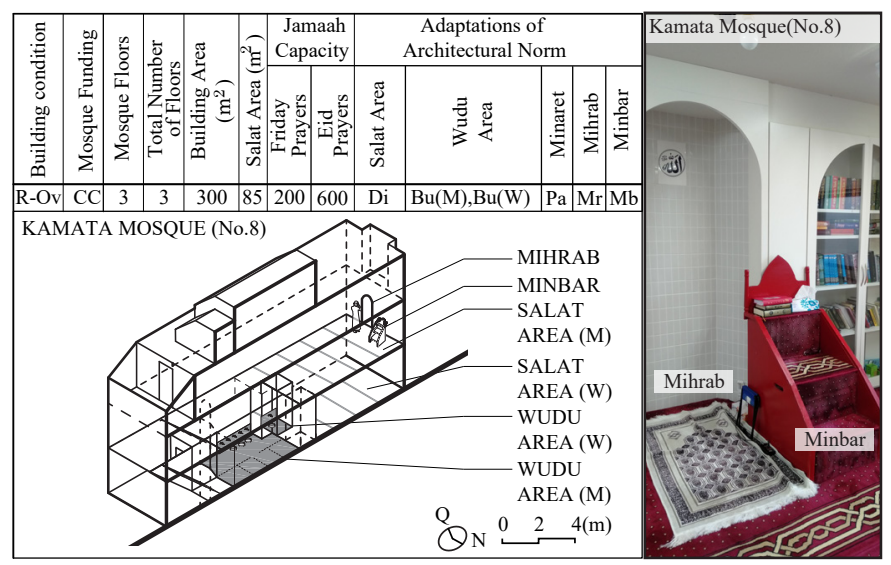

Fig. 3 Analysis Example: Kamata Mosque (No.8)
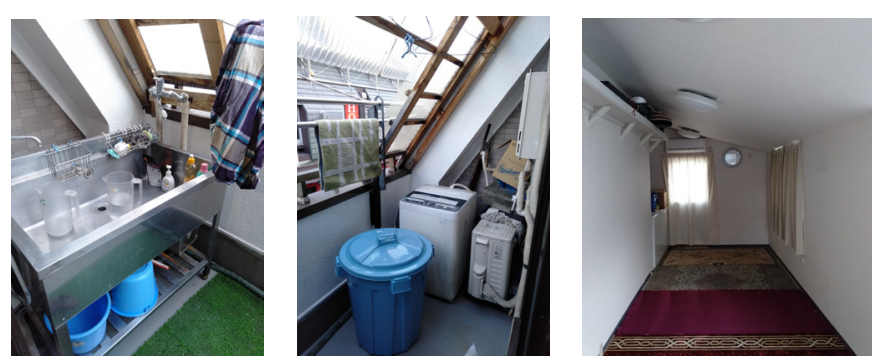

Fig. 4 Kamata Kitchen (left, centre). Imam accommodation (right)

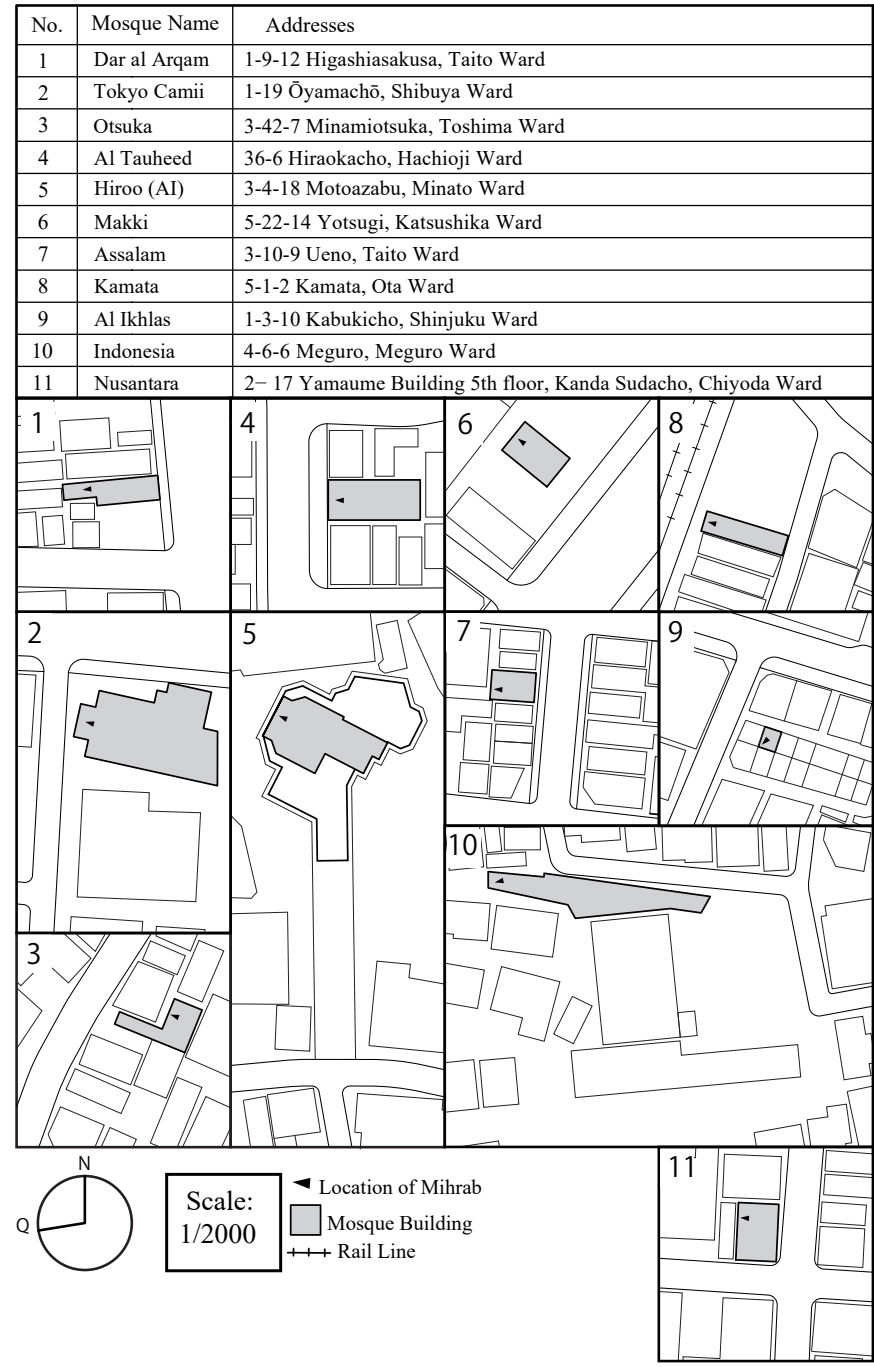

Fig. 5 Orientations of the Mosques in Tokyo according to the Qibla axis in the mosques in Tokyo, the Kamata mosque will be analyzed.

\subsection{Analysis Example of Kamata Mosque (No.8)}

Kamata mosque is an existing renovated three-storey building (Fig. 3). It is established by the community [CC]. This mosque does not have a physical Minaret. Instead, one is painted on the building facade. The Wudu area adapted an existing room on the ground floor, installing a row of taps with drainage and adding plastic seats to facilitate the cleansing ritual. Showers and toilets have also been installed. Within the Salat area, women and men are separated by floor. The ground floor is for women (W) and the first floor, which is the men's area (M), there is the Mihrab and the Minbar. The Mihrab is a decorated niche and a specifically made Minbar is for the Imam to use during Khutbah. Besides these architectural norms, there are also other functions included in the Kamata mosque. The Kitchen is where the community prepares food for events. There is also the Imam's accommodation where guest imams may use. The current Imam resides in the neighborhood (Fig. 4).

By this overview of Kamata mosque, we can see how the basic requirements to be considered a mosque can be fulfilled through the modifications of the building and furniture.

\subsection{Adaptations of Architectural Norms within Mosques}

Throughout the Muslim world, there is a great variety found in the designs of mosques. However, as mentioned before, that in order for the building to be used as one, there are the key architectural norms that must be maintained.

\section{The Mihrab wall and the spatial practice of Salat}

In mosques, physical space and behavior are inextricably linked. The practice of Salat must be done facing the Ka'abah in the city of Makkah. This axis, between the worshipper and the Ka'abah, is called the Qibla axis (Fig. 1). Ideally, the Salat space must have one wall perpendicular to the Qibla axis ${ }^{10)}$, enabling the worshippers to stand shoulder-to-shoulder facing Makkah, called the Mihrab wall. The Mihrab becomes a crucial device as it indicates which direction to face to properly perform within a building.

In a Muslim majority country, the typical mosque does not follow the urban grid but orients the Mihrab wall perpendicular to the Qibla axis. However, in Tokyo, the urban grid heavily influences the plot or building. Fig. 5 shows the orientation of the 11 mosques in Tokyo with their addresses. The Qibla (Q) axis is shown on the North arrow diagram. The Mihrab should be aligned with the Qibla axis. However, as seen in Figure 5, it is not always achievable in the condition of Tokyo. The building of the mosque in Tokyo must negotiate the orientation requirement of the Salat area, while also ensuring that internal space is used optimally. This results in an imperfect orientation of the Mihrab with the direction of Makkah, along the Qibla axis, even in the cases of purpose-built mosques.

Practices and the Adapted Architectural Norms

Each of the eleven cases was studied through the same lens to clarify the adaptations of architectural norms within the mosques in Tokyo. The adaptations of the architectural norms (Fig. 6) that were 


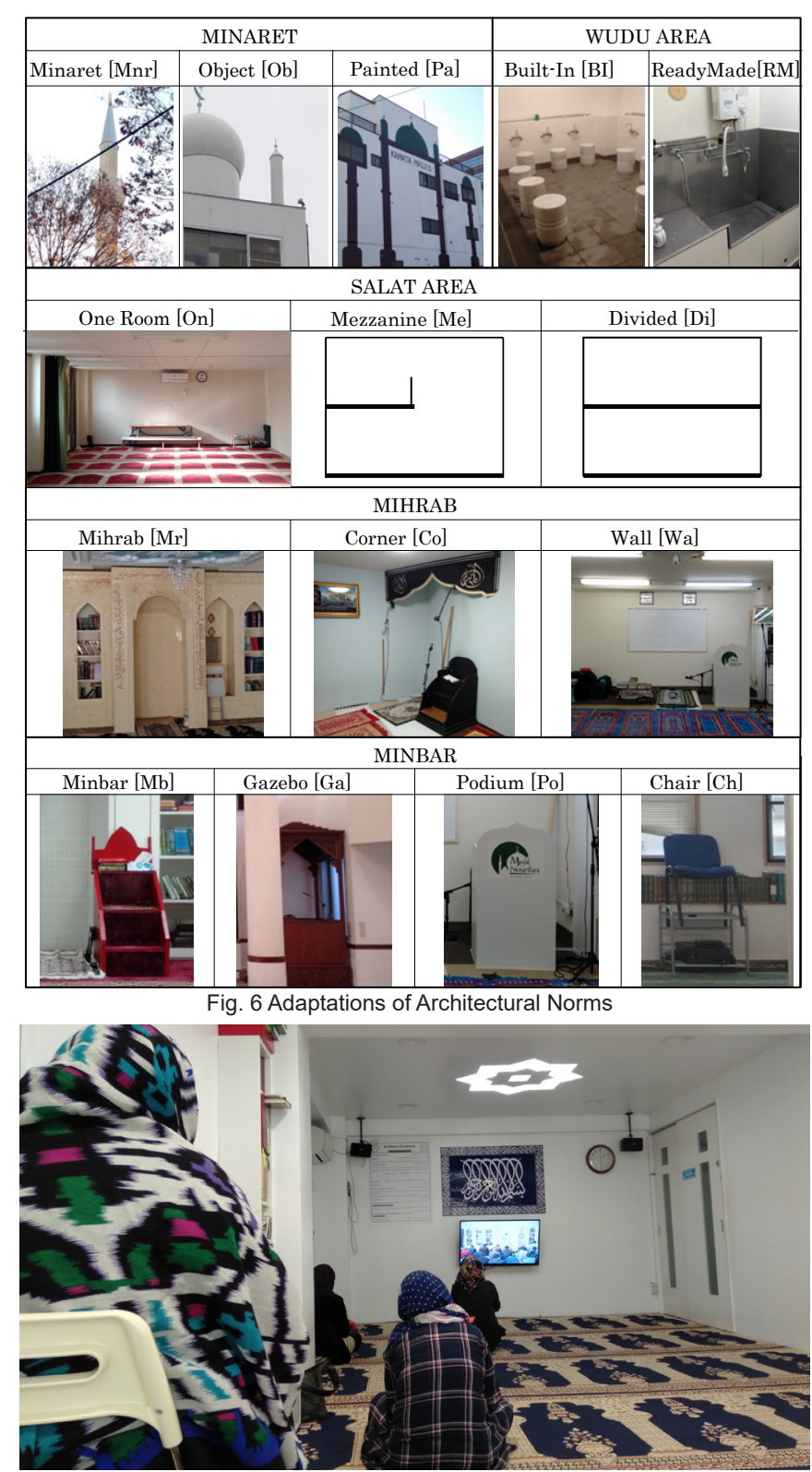

Fig. 7 Women's Jammah in Assalam Mosque using a TV monitor to watch the Imam's sermon

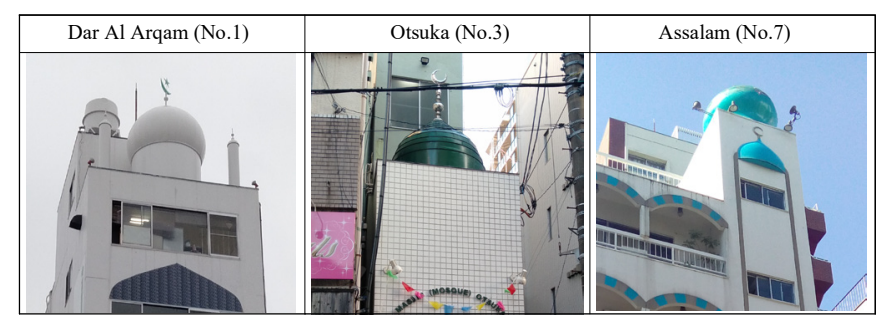

Fig. 8 Domes of Tokyo Mosque

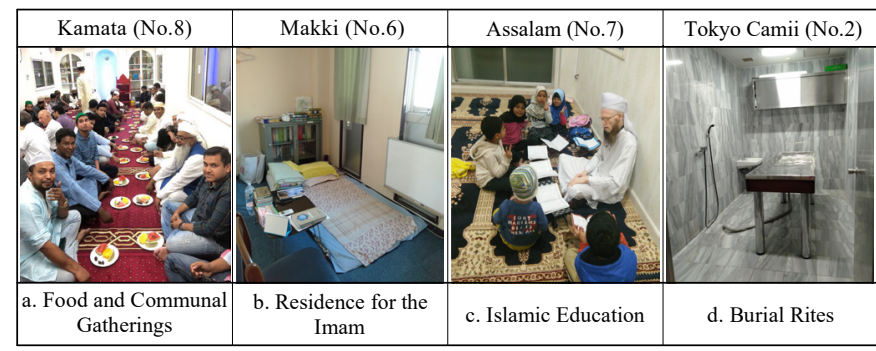

Fig. 9 Miscellaneous Rooms recorded in the case studies are below:

Practice of Adhan: In a Muslim majority country, the Adhan is an accepted practice. But a loud religious audio announcement five times a day cannot be given in Tokyo. Thus, the Minaret and its function has had to be adapted to the local condition as it is as an important architectural feature of a typical mosque. Three adaptations are seen: Typical Minaret [Mnr], the design and form of the minaret follows that of a Muslim country's Islamic architecture (No.2); Object [Ob], the Minaret devolves into an object that is attached to a building (No.1, No.3, No.4); Painted [Pa], a Minaret is painted on the façade of the building (No.6, No.7, No.8).

Practice of Wudu: The location of the Wudu area must be adjacent to the Salat, as the practice of Wudu comes before the practice of Salat. The Wudu area also needs to negotiate the practical requirements of water and drainage infrastructure, especially in renovated buildings, while being appropriately adjacent to the Salat area. This ritualistic cleanse requires the person to wash their hands, head, and feet. A place for Wudu often requires seating so that people may wash their feet comfortably. The Wudu area is separated for women (W) and men (M). This separation address two factors: (1) Many Muslim women wear the hijab, a head covering that must not be removed in front of non-family men but can be removed in front of non-family women. (2) Close proximity to the women's Salat area. In Tokyo, the mosques had two adaptations: Built-In [BI] (No. 2, No. 3, No.5, No.6, No.7, No.8, No.10), seating is built in alongside the water taps and drainage; and Ready-made Products [RP] (No.9, No. 11), where stools and other such products are bought and used. Some mosques have a combination of both (No.1, No. 4).

Practice of Salat: The main purpose of a mosque is to provide a place to practice Salat in groups that are divided by gender. Three adaptations were found: One Room [On], where the Salat is a single area (No. 6, No. 11). Nusantara (No.11) uses a curtain to divide the genders and uses a TV monitor system to provide a connection to Imam for the women's area; Mezzanine [Me], where the areas for women and men were separated by a mezzanine but maintained a visual connection from the upper area to the lower floor (No.2, No. 4, No. 5); and Divided by Floor [Di], where the areas occupied different floors (No. 1, No. 3, No.7, No. 8, No. 9, No. 10) and use TV monitors to connect the spaces. (Fig.7)

Domed ceilings play a significant symbolic role in Islamic architecture, seen in historical mosques of Iran, India and Arab countries such as Syria and Saudi Arabia ${ }^{11)}$ but is not a liturgical device and has no direct relation with the ritual practices ${ }^{12}$. In the mosques of Tokyo, out of eleven case studies, only Tokyo Camii (No.2) was successful in creating a typical domed ceiling of the Salat area, reminiscent of mosques found in Turkey. In three other mosques (No.1, No.3, No.7) takes on an ornamental role, often being attached alongside a Minaret to the exterior. (Fig. 8).

Mihrab: The Mihrab is an interior architectural norm that denotes the direction of Makkah. It is located in the men's Salat area as the 
Imam is usually male. Three adaptations were found: Mihrab [Mr], where the niche in the wall is maintained (No. 2, No 5, No.7, No.8); Corner [Co], a particular corner or niche of an existing building is modified to signify the direction of Makkah and acts as a mihrab (No.1, No.9, No.10); Wall [Wa], where the flat surface of the wall is marked with posters, curtains or whiteboards to represent the Mihrab (No. 3, No 4, No.6, No.11).

Minbar: This is a tool for the Imam to give a sermon. Three adaptations were found: Minbar [Mb], which was closest to the original form (No.1, No.2, No.6, No.8, No.9); Gazebo [Ga], a unique form of the device (No. 5); Podium [Po] or chair [Ch], where a standard podium or ordinary chairs were used (No. 4, No.7, No. 10, No.11).

\subsection{Miscellaneous Rooms}

The Muslim residents face similar issues while living in Tokyo and the mosque takes the role to address the collective needs (Fig. 9):

a) Food and Communal gatherings: Muslims have dietary restrictions due to their religion and many mosques have communal meals as part of their program as a socializing opportunity for its members. For example, Otsuka Mosque (No.3) holds a communal meal after evening prayers every Saturday. The ingredients for the meal are purchased by the mosque's fund and is prepared by volunteers of the mosque. For this practice, the kitchen [K] becomes of paramount importance as the food is prepared and served in-house. Tokyo Camii (No.2), a relatively large mosque, has a small halal food market within in addition to the kitchen. The market is a source of income for the mosque.

b) Residence for the Imam: The Imam can be considered as a representative of the mosque. He needs constant access to the mosque to lead the daily prayers and is involved in all the activities. As it is difficult to find human resources that are qualified in Islamic education within Japan, imams are usually invited by the administration from other countries. In such a case, the Imam's accommodation [Ia] is provided by the mosque. In some instances, such as Makki mosque, it is provided within the mosque.

c) Islamic Education: Formal Islamic education is not available in Tokyo and many mosques undertake to provide some basic understanding of its principles to children and adults. For that reason, amenities such as libraries [Lb] are included to keep multilingual literature about the Islamic religion, multipurpose rooms [Mlt] and class rooms $[\mathrm{Cr}]$ to conduct classes, events and seminars.

d) Burial Rites: Muslims have specific rituals in place following the death of a member of their religion. As institutions facilitating these rituals are not available in Tokyo, it has become part of the mosque as the Jenazah room [Jr] in the Dar Al Arqam (No.1), Tokyo Camii (No.2) and Al-Tauheed (No.4) mosques. Here, the remains of the deceased are cleansed according to Islamic rituals before burial.

The above analysis clarifies the modifications the architectural norms undergo in order to adapt the spatial practices of the behavioral norms to the context of Tokyo (Table 3).

\section{Adaptation Patterns of the Case Studies}

Table 3 Pattern Analysis of Architectural Norms within Mosques

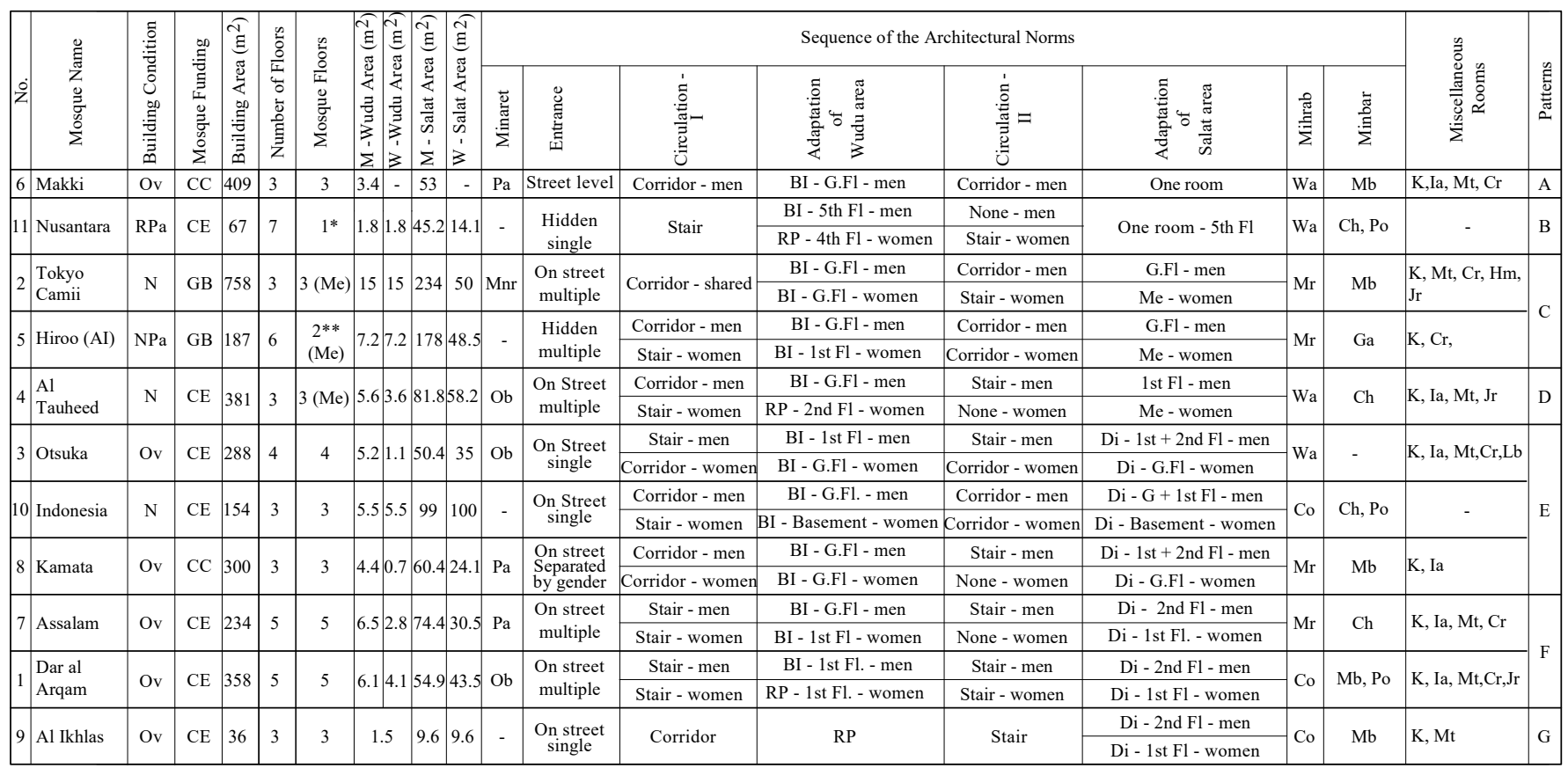

*) Only 5th Floor is used as the mosque **) Only 1st and 2nd Floors are used as the mosque

Legend for Table 3

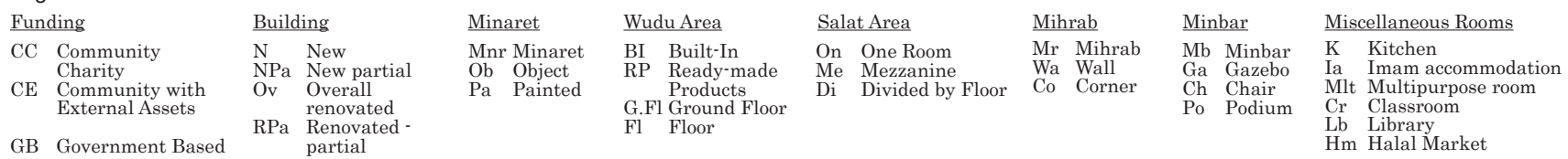




\subsection{The Sequence of Architectural Norms within Mosques}

As mentioned in the section of Methodology, a sequence of behavioral norms is followed in a mosque. In Table 3, this sequence that takes place from the practice of Adhan to the practice of Salat is explained as it occurs in the mosques in Tokyo. Table 3 shows the number of floors in the building that are used as the mosque and how much of the total building area $\left(\mathrm{m}^{2}\right)$ of each mosque is dedicated to the practice of Wudu and Salat. The entrance is either visible from the street [On street] or hidden within the building [Hidden] There may be a single entrance, or multiple, or it is separated by gender. After entry, women and men separate towards their respective Wudu and Salat areas. Circulation-I connects the entrance to the Wudu area. Circulation-II connects the Wudu and Salat areas.
The separation of women and men along the sequence is termed as "branching."

Makki (No.6) has no space allotted for women within the mosque. Kamata (No.8) begins branching at the entrance that is separated by gender. In Al Ikhlas (No.9), both men and women use the same circulation and Wudu area but branch off only in the Salat area. With Nusantara (No.11) the branching begins with the separation of the Wudu areas. Tokyo Camii (No.2) has women and men share circulation but maintains the separation of Wudu and Salat areas by gender. In the remaining six cases (No.1,No.3, No.4, No.5, No.7, No.10) the branching begins at Circulation-I.

It is seen that the respective Wudu areas for women and men come sequentially before the respective Salat areas by occupying the

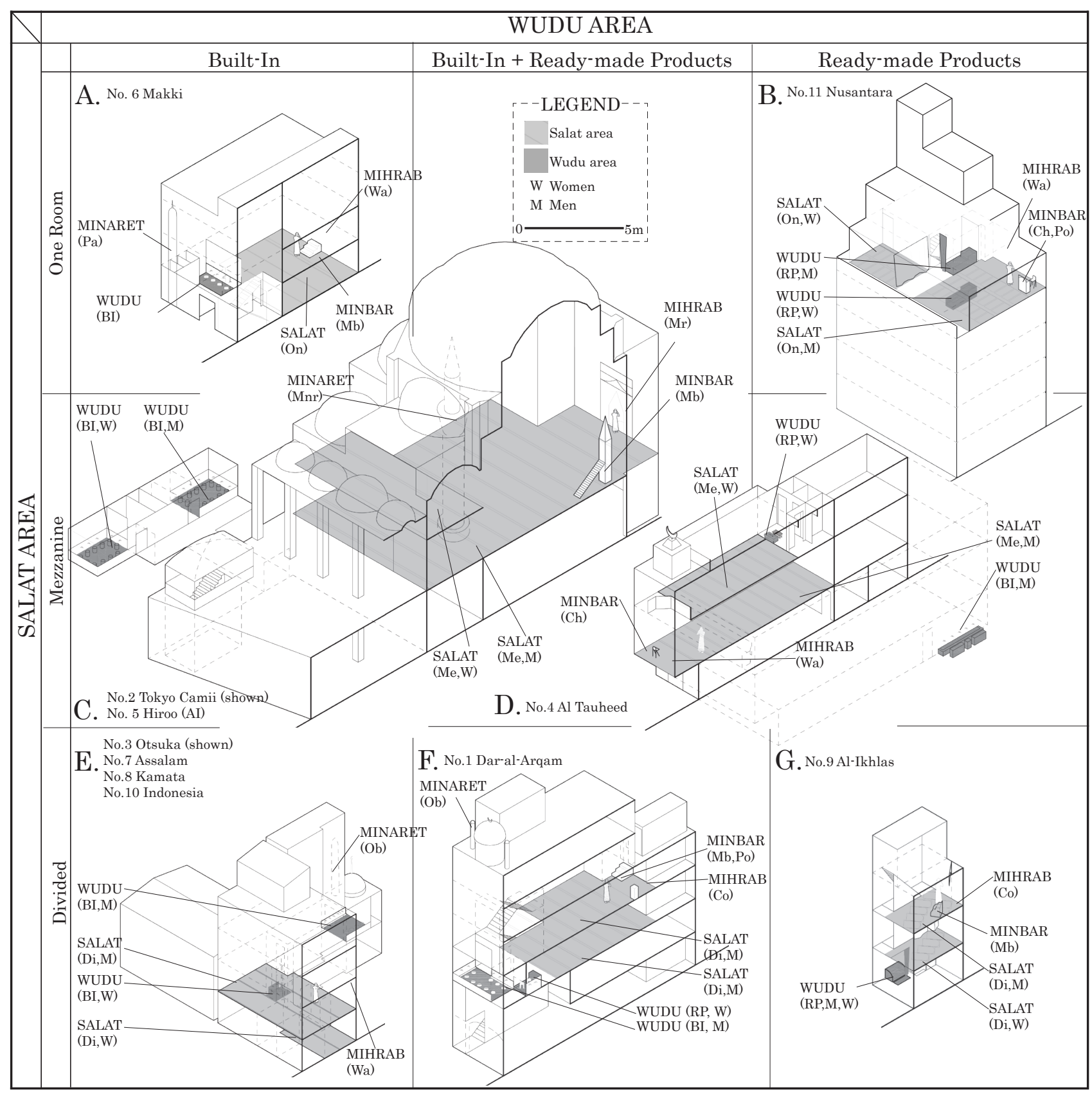

Fig. 10 Patterns of Adaptation of Mosques in Tokyo 
same or lower floors. In four cases (No.1, No.4, No.7, No.8), the women's Wudu area opens directly into their Salat area without Circulation-II. This adjacency reinforces the sequence of behavioral norms where Wudu is performed before the Salat.

The above analysis clarifies that the modifications of the architectural norms in the condition of Tokyo facilitate the spatial practices of a mosque. Conflicts arise when transposing the requirements of a mosque onto the physical condition of Tokyo. The behavioral norm that encounters the public, such as people using the street, nearby residents as well as schools or shops, the Adhan, is removed. In the case studies, only Tokyo Camii has a traditional Minaret but cannot perform the vocal announcements. All others have Minarets reduced to only visual markers. Within the mosque building, the architectural norms have degrees of adaptation. The Wudu area is an important factor that cannot be removed. It often needs to be renovated as seating is required for the behavioral norm of the Wudu. Seven out of 11 mosques had Built-In Wudu areas (No. 2, No. 3, No.5, No.6, No.7, No.8, No.10) and two used a combination of Builtin with ready-made products (No.1, No. 4).

The separation of women and men is maintained in all of the 11 mosques in both Wudu and Salat areas. Only mosques with $\mathrm{Mez}^{-}$ zanines in the Salat areas (No.2, No.4, No.5) had a direct visual connection between women's area to the Imam in the men's areas. Only four mosques have typical Mihrabs (No.2, No.5, No.7, No.8), while the remaining have simplified versions of marked walls or cor ners. Five (No.2, No.6, No.7, No.8,No.9) out of eleven mosques used Minbars since these devices are not commonly found and require to be specially made. These adaptations are done according to the financial assistance available to the mosque.

The primary function of the mosque is to provide a space for the communal practice of Salat. Thus, the Salat and Wudu areas become crucial factors in a mosque and were taken to organize the 11 case studies into seven patterns (Table 3).

-Pattern A: Salat area is One room and Wudu area is Built-In.

-Pattern B: Salat area is One room and Wudu area has Ready-made Products.

-Pattern C: Salat area has a Mezzanine and Wudu area is Built-In. -Pattern D: Salat area has a Mezzanine and Wudu area has a combination of Built-In and Ready-made Products.

-Pattern E: Salat area is Divided by floor and Wudu area is Built-In. -Pattern F: Salat area is Divided by floor and Wudu area has a combination of Built-In and Ready-made Products.

-Pattern G: Salat area is Divided by floor and Wudu area has Readymade Products.

Using the patterns, the mosques can then be arranged in the matrix (Fig. 10) according to the Wudu and Salat areas. For the Wudu areas, the horizontal axis is composed of the categories of ReadyMade, Built-In and the combination of Built-In+ Ready-made Products. The vertical axis relates to the adaptations found in the Salat area: One Room, Mezzanine and Divided. The matrix of Fig. 10 elab- orates the variety found in the Tokyo mosques, in scale, in building form as well as the combinations of adaptation of the architectural norms that they use. An example of each pattern is shown.

5.2 Architectural Expression and the Relationship between Mosque

\section{Management and the Adaptations of the Architectural Norms}

Taking the clarification of the adaptations of the architectural norms alongside the information discussed through Building, People and Activities in the management of the mosques, it is seen that while all mosques provide a space for the communal Salat, they are not identical and have additional aspects which differentiate one from the other.

Tokyo Camii (No.2) prioritizes Turkish national identity in addition to its Islamic identity. Its origins are celebrated as Turkish artisans and craftspeople were invited to be involved the construction. Within the mosque, the Salat area is the central space beneath the greatest dome, reminiscent of Turkish mosques, with the Wudu areas purpose built and neatly tucked away. The Minbar and Mihrab are replicas of those found in Turkish Ottoman mosques and are purpose built devices to facilitate the ritual of Salat and Khutbah. Hiroo (No.5) and Indonesia mosque (No.10) also refer to their Islamic religion alongside their culture. However, they are annexes, Hiroo mosque being part of the Arab Institute and Indonesia mosque being part of the Indonesian school.

On the other hand, there are mosques that formed by the efforts of local Muslim residents in Tokyo independent of one culture or country. Dar al Arqam (No.1), Otsuka (No.3), Makki (No.6), Assalam (No.7), Kamata (No.8), Nusantara (No.11) all appropriated commonly found office buildings into a religious facility. The local Muslim residents participate in establishing the mosque, either through financial assistance, or physically building the mosque or taking part in administrative decisions. In order to communicate the Islamic identity, generic forms Minarets or domes were either attached or painted onto the facade of the building. The variations of the architectural adaptations of the Mihrab are used according to the financial ability of the mosques and common objects such as chairs or podiums may be used as Minbars. This appropriation of buildings and furniture to facilitate the spatial practices of Salat and Wudu indicates the versatility of the mosques. In contrast to Tokyo Camii, the mosques do not promote a single nationality.

Thus, while the mosques share their goal in providing a space for communal Salat to visitors of diverse backgrounds, their management and methods of architectural adaptations enable them to reflect a particular country or focus only on the Islamic religious identity.

\section{Conclusion}

Japan, being a non-Muslim majority country has a small number of mosques, which differ in scale, methods of establishment, and architectural expression. As religious facilities, they have architectural norms that are used if the behavioral norms are to be practiced 
correctly. These mosques transpose architectural norms of typical mosques found in Muslim majority countries onto the local available physical setting in Tokyo. This study focuses on how architectural norms of mosques are modified when encountering the building and social conditions of the Tokyo to ensure that the unchangable ritual behavior can be practiced.

It was determined that a typical mosque found in Muslim majority countries cannot be perfectly replicated in Tokyo, with conflicts arising between the typical architectural norms and the urban condition.

There were varying degrees of adaptation in the mosque building. In the behavioral norm of Adhan, the associated architectural norm of the Minaret was reduced to only being visual marker and the vocal practice of Adhan was removed. The architectural norm of the Wudu area has only the basic requirements for the behavioral norm of Wudu and cannot be removed. In the case of a renovated building, it must negotiate with the existing infrastructure while being situated adjacent to the Salat area. Both the Wudu and Salat areas are separated by gender. As the Imam is in the men's Salat area, this separation forces renovated mosques to rely on devices like TV monitor systems to connect the two Salat areas. Only the three mosques that had Mezzanine levels could provide a direct connection between the Imam and women's Salat area. Within the Salat area, only four mosques had conventional Mihrabs, while the remainder marked walls or corners to show the direction of Makkah. Five mosques had Minbars while the remaining used chairs or podiums instead.

The analysis clarifies that it was the architectural norms that had to be adapted for the optimal performance of the behavioral norms, whether the building is purpose-built as a mosque or an existing building renovated into one. It was determined that the Salat and Wudu areas are crucial factors in the mosque. Thus, they were used to categorize the mosques into seven patterns from A - G. The variety of patterns informs of the different manner and combinations in which the architectural adaptations can be executed when responding to Tokyo's conditions.

The mosques share a similar goal, i.e., to provide a space for the practice of Salat in a communal way, negotiating with the limitations they face in Tokyo. Yet they are not identical to one another. Some prioritize a nationality in addition to the religion while others focus solely on their Islamic religious identity.

The number of mosques remains small in Tokyo but they give us the opportunity to analyze how the architectural norms are modified in order to accommodate the behavior of spatial practices.

\section{References}

1) Komai, H.: Foreign migrants in contemporary Japan, Trans Pacific Press. 2001

2) Tanada, H.: Mosques of Japan, Social Activities of Muslims in Japan, Yamakawa Publishing 2017 (In Japanese) 店田廣文：日本のモスク, 滞日ムスリムの社会的活動, 山川出版社 2017

3) Tanada, H., Okai, H.: Islam of Japan,Current status and issues of
Muslim Communities in Japan, Shumu Jiho 119, pp. 1-22, 2015.3 (In Japanese)

店田廣文, 岡井 宏文：日本のイスラム , ムスリムコミュニティの現状と 課，宗務時報 (119), pp. 1-22, 2015.3

4) Okai, H.: Establishment of Religious Institutions by Muslim Immigrants in Japan, Waseda Journal of Human Sciences 22-1, pp. 15-29, 2009 (In Japanese)

岡井 宏文：滞日ムスリムによる宗教的基盤の獲得と変容 - モスク設立活動 を中心に - , 人間科学研究, 第 22 巻, 第 1 号, pp. 15-29, 2009

5) Amin, A.: From Mushalla to Mosque, The Formation of South and Southeast Asian Muslim Communities in Japan, Al-Albab, 8(1), pp. 3 20,2019

6) Kawazoe, W.: Study on the Role and Expansion of Islamic Facility in Japan, in the Era of Foreigner Settlement, A Case Study In Masjid Otsuka in Toshima-ward, Tokyo, The New Geography, 65(3), pp. 16-33, 2017 (In Japanese)

外国人定住化時代におけるイスラーム系宗教施設の役割とその拡 大 一 東 京都豊島区 [マスジド大塚 ] を事例として，新地理 65-3，pp. 16-33， 2017

7) Lefebvre, H.: The Production of Space, translated by Donald NicholsonSmith, Blackwell Publishers, 1991

8) Knott, K.: The Location of Religion, Durham, Acumen, 2005

9) Frishman, M., Khan,H., Al-Asad,M.: The mosque, history, architectural development and regional diversity, Thames and Hudson, 1994

10) Kahera, A., Abdulmalik, L., Craig.: Design Criteria for Mosques and Islamic Centers: Art, Architecture and Worship, Elsevier Ltd, 2009

11) Hillenbrand, R.: Islamic Architecture: form, function and meaning, Edinburgh University Press, 1994

12) Tajuddin, M and Rasdi, M: Rethinking the Mosque in Modern Muslim Society, Institute Terjemahan Negara Malaysia, 2014

13) Stierlin, H., translated by Kamiya Takeyo: Architecture De L'Islam, Hara-Shobo, 1987 (In Japanese) アンリ・スチールラン．神谷武夫訳．イスラムの建築文化．原書房 . 1987

Notes

*1) Tanada listed eight mosques and this study found an additional three examples.

*2) Tanada explained there are four types of establishment methods of mosques in Japan: Country-based, Community with personal charity's, Community base personal assets, Community and external assets and Foreign students community. 


\section{Summary in Japanese}

東京に住むムスリムは、自身の宗教的活動を継続するために数々のモスクを建設してきたが、その多くは礼拝に欠かすことができない行為規 範を遂行するなかで、モスクの建築規範を既存の物的環境に適応させている。本稿では、東京におけるモスク11事例を対象に、運営者への聞 取および現地調查で得られた情報から、各事例における建築規範の適応を検討寸ることで、ムスリムのアイデンティティに関わる、東京にお けるモスクの多様な実践を明らかにすることを目的とする。

ムスリム多数派の国にみられる典型的モスクにおいては、礼扯の行為規範であるアザーン、ウドゥー、イカーマ、サラート、フトバは、特定 の建築規範と結合している。礼拝のはじまりを告げるアザーンはミナレットで行われ、身を清めるウドゥーは洗い場であるウドウーエリアで 行われる。教徒が集い祈りを捧げるサラートは、モスクの主たる場であるサラートエリアで行われ、ここにはキブラの方向を示すミフラーブ と、指導者であるイマームがイカーマとフトバを行う説教台ミンバルがある。

新築4例、改修7例を含む全事例について、建築規範の適応を検討したところ、ミナレットには、内部をもつミナレットのほか、物体を取り付 けたもの、外壁にペイントされたものがみられた。ウドゥーエリアには、造り付けのほか、既製品を用いた洗い場がみられた。サラートエリ アには、一室のほか、性差に対応した中二階をもつもの、性差ごとに各階に分けるものがみられた。ミフラーブには、壁面に対する凹みであ るミフラーブのほか、室内の角を用いるもの、凹みのない壁面を用いたるのがみられた。ミンバルには、段状の説教台であるミンバルのほ か、見晴らし台状のガゼボ、腰かけるのみの演台や椅子がみられた。

続いて事例ごとに建築規範の適応を行為規範の順にそったシークエンスとしてまとめたところ、東京において典型的モスクが再現されること はなく、モスクの実践と都市の条件との間の衝突が建築規範の適応に示されているといえる。全事例でアザーンは省略され、ミナレットは行 為規範を伴わずに適応されている。他方でウドゥーとサラートは、建築規範としての適応を被りつつも不可欠な行為規範として決して取り除 かれることはない。またウドゥーエリアとサラートエリアにおける女性用と男性用の分離は、全事例で維持されている重要な要素である。こ れより、ウドゥーエリアとサラートエリアにおける適応の組み合わせが共通するものとして、東京のモスクにおける建築規範の適応パタンを 整理した。サラートを一室で行い、ウドゥーエリアを造り付けるA、既製品によるB、サラートを性差に対応した中二階で行い、ウドゥーエリ アを造り付けるC、造り付けと既製品による洗い場をともにもつD、サラートを性差に対応して各階で行い、ウドウーエリアを造り付けるE、造 り付けと既製品による洗い場をともにもつF、既製品のみによるGである。

各事例は建物内に礼扯に用いない雑多な室が併設される傾向にある。またドームのように特定の地域による建築要素を用いた事例や、特定の 国によって設立された施設に付属する事例がみられる。以上を総合すると、東京におけるモスクの実践には、建築規範の適応をとおした宗教 の行為規範にもとづく礼拝機会の提供に、特定の国や地域の文化の影響が重対られており、東京においてムスリムとしてのアイデンティティ を保つことを容易にする多様な実践が映し出されているといえる。

\section{Summary in English}

In a Muslim-majority country, the mosque is a significant urban facility found throughout the city. As Japan is not Muslim-majority country, the number of mosques is quite small. The typical mosque is deconstructed into behavioral norms and their associated architectural norms that must be maintained by the facility to be used as a mosque in Tokyo. Each of the behavioral norms, Adhan, Wudu, Iqamah, Salat and Khutbah, are associated with an architectural norm. The Adhan is given at the Minaret. The Wudu is performed in the Wudhu area. Salat is performed in the Salat area that contains the Minbar and Mihrab, where the Khutbah and Iqamah are also performed. This study takes the 11 mosques in Tokyo as case studies. Through interviews with the users and field surveys, the management of the mosque, sequence and adaptations of each of the mosques was examined. The case studies show how architectural norms are modified to accommodate specific behaviors of religious practices.In Tokyo, different adaptations of the architectural norms are found. In Minaret, there are: Typical Minaret, Object and Painted. In Wudu area, there are: Built-In and ready-made Products. In the Salat area, there are: One Room, Mezzanine and Divided. In Mihrab, there are: Mihrab, Corner and Wall. In Minbar: Typical Minbar, Gazebo, Podium and Chair. A typical mosque cannot be perfectly replicated in Tokyo, with many conflicts arising between the typical architectural norms and the city condition. The practice of Adhan is removed, devolving the minaret into non-functional adaptations. But practices such as Wudu and Salat are crucial to a mosque and their associated areas were adapted but never removed. The separation of women and men in the Salat and Wudu areas is an important factor in each of the mosques. The Wudu and Salat areas are used to compare the different mosques and to organize them into seven patterns of adaptations, from A - G. A: the Salat is One room and the Wudu is Built-In; B: the Salat area is One room and the Wudu area has Ready-made Products; C: the Salat area is divided by a Mezzanine and Wudu area is Built-in; D: the Salat area is divided by a Mezzanine and the Wudu area is combination of Built-in and Ready-made Products; E: the Salat area is divided by floor and Wudu area is Built-in; F: the Salat area is divided by floor and Wudu area is combination of Built-in and Ready-made Products; G: the Salat area is divided by floor and Wudu area has Ready-made Products. After clarifying the management of the mosques and the adaptations of the architectural norms, it was seen that while all mosques provide a space for communal Salat, some cases are established with the cultural influences of a certain country, either as an independent facility or an annex to an institution, while others do not. The mosques in Tokyo display the diverse practices that the mosques undertake to facilitate the Muslim identity. 